ENHANCING THE EXPERIENCE OF EATING AND DRINKING THROUGH SMELL 1

RUNNING HEAD: ENHANCING THE EXPERIENCE OF EATING AND DRINKING THROUGH SMELL

\title{
Enhancing the Experience of Food and Drink via Neuroscience-Inspired Olfactory Design
}

\author{
Prof. Charles Spence
}

Crossmodal Research Laboratory, University of Oxford

DATE: DECEMBER, 2016

IN PRESS: THE SENSES AND SOCIETY

CORRESPONDENCE TO: Prof. Charles Spence, Department of Experimental

Psychology, University of Oxford, South Parks Road, Oxford, OX1 3UD, U.K.

TEL: +44-1865-271364; FAX: +44-1865-310447; E-MAIL: charles.spence@psy.ox.ac.uk 


\begin{abstract}
Olfactory cues, both orthonasal (when we inhale) and retronasal (when we swallow/breathe out from the back of the nose), play a crucial role in the experience, and enjoyment, of food and drink. However, the design of product packaging glassware, and even plateware has typically not been optimized to deliver the ideal orthonasal hit. This review highlights a number of recent attempts by packaging manufacturers to improve the orthonasal experience for the consumer. The various ways in which modernist chefs, molecular mixologists, culinary artists, and designers have been playing with the delivery of both foreground and background aromas and scents in order to complement the dishes and drinks they serve is also examined. Finally, I highlight some of the ways that technology may be used to deliver food aromas in the future, and stress the need for more research in order to determine whether enhanced olfactory design (e.g., in scent-enabled cutlery and packaging) may one day be used to help nudge consumers toward healthier eating behaviours. The important distinction between natural and synthetic (or better said, between perceived natural vs. perceived synthetic) aromas is also discussed, as this will likely play an important role in determining the future uptake of such innovative olfactory delivery solutions in the future.
\end{abstract}

KEYWORDS: OLFACTION; DESIGN; GASTROPHYSICS; MULTISENSORY; EXPERIENTIAL. 


\section{Introduction}

Although estimates vary, most researchers would seem to agree that smell contributes the majority of the sensory input as far as our experience, not to mention enjoyment, of food and drink is concerned (Spence, 2015a). While the taste buds on the tongue provide information about the basic tastes (e.g., sweet, sour, salty, bitter, umami, metallic, fatty acid...... and who knows, maybe a few more as well; Stuckey, 2012; see also Lapper, Penner, \& Lim, 2016), it is the olfactory receptors in the nasal mucosa that tell us about fruity, meaty, floral, herbal, burnt aromas, etc. (Spence, 2015b). Ironically, though, most of the time, we are unaware of just how much of the information that we think we taste (via the tongue) is actually transduced by the nose, in large part because of the phenomenon of oral referral (see Spence, 2016, for a review): Specifically, olfactory stimuli detected at the nasal mucosa are experienced as if coming from the mouth - that is, as if sensed by the tongue (though researchers are less sure when it comes to the question of whether we should think of this as an example of fusion, sensory dominance, or confusion see Spence, 2016).

Scientists have, for a century or so now, been laboring under the mistaken impression that oral referral resulted from the tactile stimulation of the oral cavity that inevitably occur whenever we eat and drink (see Hollingworth \& Poffenberger, 1917, for an early statement along these lines). The belief was that it was the tactile stimulation in the mouth that is inevitably associated with eating and drinking that served to ventriloquise the aroma to the oral cavity, in much the same way as the voice is ventriloquized to the speaker's lips in the ventriloquist's dummy illusion (Alais \& Burr, 2004). However, the research actually shows that the strength of oral referral depends primarily on the congruency between the retronasal olfactory and gustatory inputs instead (Lim \& Johnson, 2011, 2012). ${ }^{1}$ The aroma of vanilla, say, being mislocalized to the oral cavity far more frequently when there is a sweet tastant in the mouth rather than a salty one (see Spence, 2016, for a review).

Many of our everyday food experiences are not optimized to deliver the best orthonasal aroma hit. This is important because sniffing allows us (or rather, our brains) to form flavour expectations concerning both what the experience of tasting will be like, and how much we may enjoy it (see Piqueras-Fiszman \& Spence, 2015, for a review). Just take, as an example

\footnotetext{
${ }^{1}$ Retronasal olfaction occurs when volatile odours are pulsed out of the back of the mouth and into the nose when swallowing and breathing out through the nose (see Ni et al., 2015). Olfaction occurs orthonasally when we sniff external aromas from the environment (Fincks, 1886; Rozin, 1982).
} 
of poor orthonasal olfactory design, all of those plastic lids routinely placed over Styrofoam cups of hot coffee and tea each and every day around the world (Spence, 2015c). While they undoubtedly allow the consumer to drink their beverage without having to worry about spillage, what these lids singly fail to do is to allow the consumer to appreciate the orthonasal aroma of the contents by sniffing. Unfortunate, really, given that the research suggests that the smell of freshly-ground coffee is actually one of the most liked of smells (Ayabe-Kanabe et al., 1998). The same problem occurs whenever we drink direct from a bottle or can. Once again, the problem is simply that the orthonasal olfactory component is missing. So, having identified the problem, what's to be done? In terms of design, simple solutions include the reshaping of the lid, and the addition of a second opening in order to allow the coffee afficionado to sniff the aroma of their hot beverage. This is part of the solution incorporated into the ergonomic orthonasal aroma delivery lid introduced by Viora Ltd., see http://www.vioralid.com/; Mangen, 2014). Or one might consider the 360 lid from of Crown Packaging (http://www.crowncork.com/beverage-packaging/innovations-beverage-cans/360end). The top of these can lifts off, thus allowing the drinker to see and orthonasally sniff the contents more easily than when drinking from a traditional can (see Figure 1).

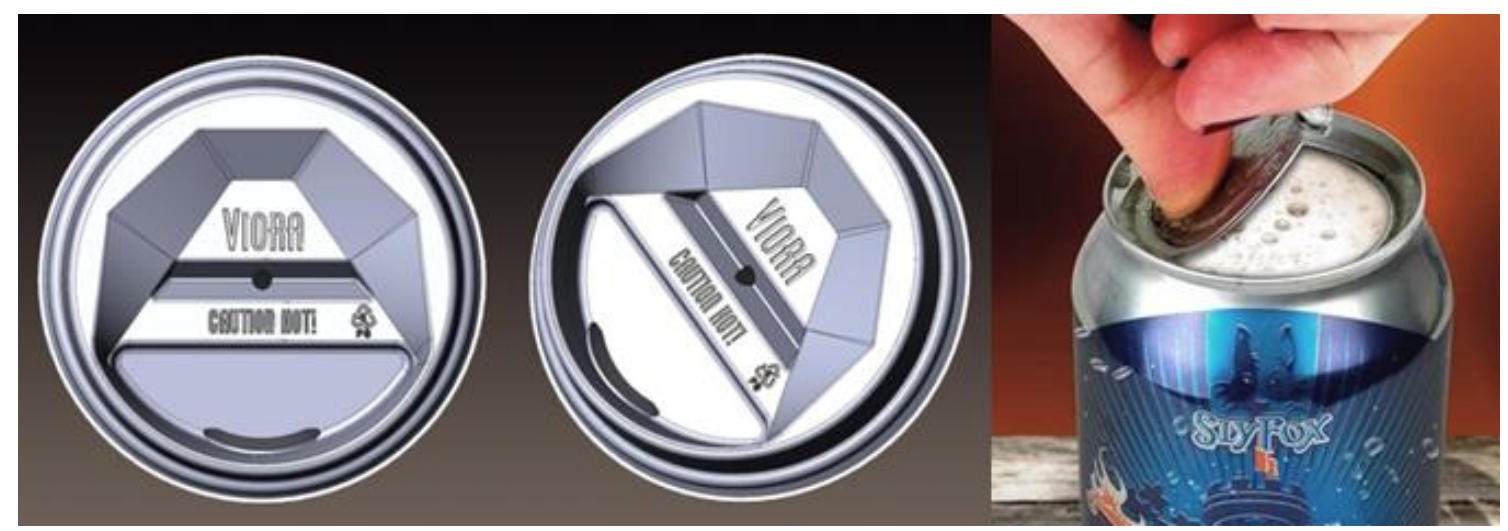

Figure 1. Two examples of enhanced design. The Viora lid and the Crown's 360End ${ }^{\mathrm{TM}}$ can. [Figures reprinted from http://www.vioralid.com/; and http://www.crowncork.com/beverage-packaging/innovations-beveragecans/360-end.]

Let's now take a contrast case. At the opposite extreme from the lid, bottle, or can that resolutely prevents the consumer from orthonasally enjoying the aroma of their drink, consider the traditional pint. Back when all beers seemed to taste the same, or better said, 
where consumers were time-and-again shown to be unable to pick their favourite brand in the blind taste test (e.g., Allison \& Uhl, 1964; Robinson, 2014), the lack of any headspace over the drink in the glass probably didn't matter all that much. However, a craft beer revolution has swept the nation in recent decades and there are now a host of beers that people are obviously willing to pay a hefty premium, and that really do taste of something distinctive for a change (Elzinga et al., 2015). It can be argued, therefore that perhaps it is time to think again about the design of the glass in which so many pints are served.

In the case of wine, of course, the empty headspace over the liquid in a glass is meant to help preserve the aroma and bouquet so as to delight the taster's nostrils (see Spence \& Wan, 2015 , for a review). The better the wine, the larger the volume of headspace in the glass or so it would seem. But what of the aroma of one's craft beer? How much of it is lost to the atmosphere? If we value the flavour and aroma so much maybe it really is time to think a little more seriously about a redesign, ideally so that enough room is left to offer the drinker's nostrils an aromatic headspace in the glass above the beer when served. ${ }^{2}$ Now, one might be tempted to argue that this doesn't really matter; After all, or so people say, as soon as the drinker has had a few drafts of their beer, they will have created an aromatic headspace in their glass anyway. While this undoubtedly helps, I think that the key point to stress here is that it is so often the first mouthful, and even the initial sniff before tasting, that sets our sensory and hedonic expectations about what is to come. And it is these expectations that end up anchoring and hence disproportionately influencing the overall tasting experience (i.e., when compared to the influence of the last mouthful, say). An alternative solution, of course, would simply be to dust off those old beer glasses, such as those Steiners, that came with a lid. The aim, at least according to Fincks (1886, p. 693) writing 130 years ago was to protect the gases released from the surface of the beer.

\section{Enhanced flavour delivery}

Many of the world's top modernist chefs and molecular mixologists have also been thinking creatively about how to deliver enhanced multisensory dining and drinking experiences through the more intelligent delivery of aroma and scent (e.g., see Anonymous, 2011;

\footnotetext{
${ }^{2}$ Assuming, that is, that the customer doesn't immediately think that they are being short-changed by a glass that is anything less than full to the brim.
} 
Koutsovoulou, 2014; Spence \& Piqueras-Fiszman, 2014). At its simplest, some are adding aroma that they hope will be integrated into the flavour of the dish: Think here, for example, of the use of the atomizer to deliver the aroma of vinegar over the fish and chips dish served at Heston Blumenthal's The Perfectionist's Café at Heathrow's Terminal 2 (see http://www.theperfectionistscafe.com/; Yeap, 2015). ${ }^{3}$ London-based chef, Jozef Youssef (see https://kitchen-theory.com/) has also been experimenting with the use of atomizers to deliver aroma (not to mention a dash of theatre) to a number of his dishes.

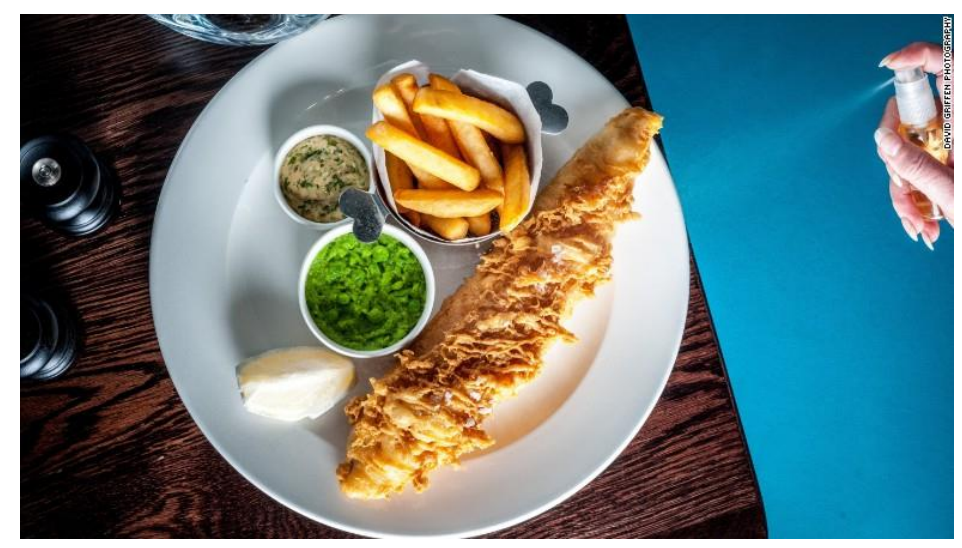

Figure 2. Fish, chips, and mushy peas, together with atomized vinegar, as served at Heston Blumenthal's The Perfectionist's Café. [Figure reprinted from Yeap, 2015).]

Note here, though, that it the Italian Futurists were most probably who actually deserve the credit for first using atomizers at the dining table. That said, they were more likely to spray perfume (e.g., the smell of carnation) into their diners' faces should they were foolish enough to look up from their plate (see Marinetti \& Colombo, 1930, 1998, p. 43; Spence \& Youssef, 2015). Quite what effect this had on the flavour of the food, or the multisensory tasting experience, has sadly not been recorded for posterity! Nowadays, though, a growing number of chefs and mixologists are going well beyond the atomizer, and using smoking guns to deliver smoked aromas, and dry ice based cloud pourers to deliver especially concentrated aromas to a dish or drink, often with an added dash of theatricality too.

\footnotetext{
${ }^{3}$ On a side note, is it not interesting how little aroma there is in airports? Walk into a rail station or book store and your nostrils will likely be assaulted by the smell of coffee. Airports, by contrast, appear to be olfactorily neutral spaces. Though see Cable (2014) for one intriguing recent exception to the claim that airports are always aroma-free.
} 


\section{Setting the olfactory scene}

However, it is important to note that aromas that are not necessarily part of the flavour of the dish are now being added to dishes, drinks, the dining table, or even, on occasion, to an entire dining room with the aim of creating a particular atmosphere or mood, or else to trigger a specific memory in the mind of the drinker or diner. ${ }^{4}$ Think here, for example, of Blumenthal's moss-scented dish served at his flagship The Fat Duck restaurant (http://www.thefatduck.co.uk/), or the hot water poured over the hyacinths at Alinea in Chicago (https://website.alinearestaurant.com/), when the Wild Turbot, Shellfish, Water Chestnuts, and Hyacinth Vapor dish is served. Grant Achatz, the head chef, is also known for the smell of burning oak leaves that accompanies his pheasant, served with shallot, and cider gel dish (see Figure 3). The idea here is to use scent to try and trigger pleasant childhood memories of an autumnal day (see Anonymous, 2011; Spence \& Youssef, 2015).

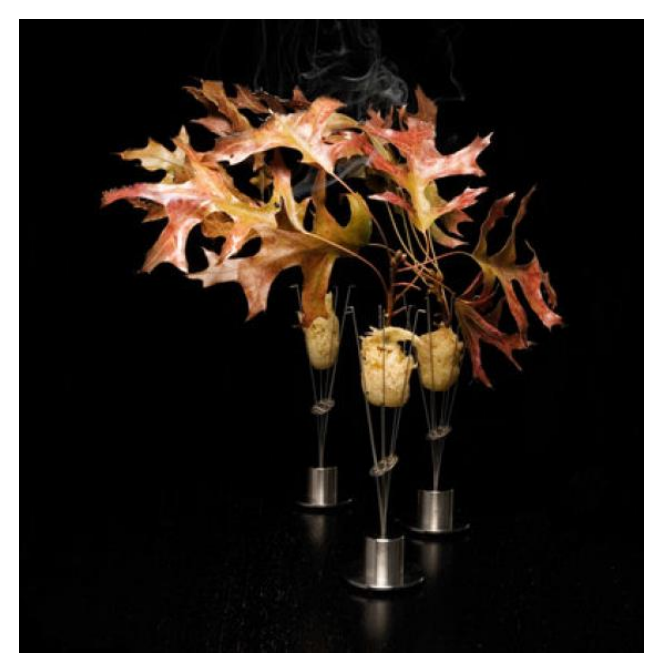

Figure 3. The Wild Turbot, Shellfish, Water Chestnuts, and Hyacinth Vapor dish served by Grant Achatz at Alinea in Chicago. While the smell of burning leaves may not be that tasty in-and-of-itself, the aim is rather to help set the scene, and provoke specific memories in the mind of the diner [Figure reprinted from Anonymous (2011).]

\footnotetext{
${ }^{4}$ Note that in ancient Greece or Rome, the fragrance of fresh flowers, perfumed unguents and incense was an essential accompaniment for a successful dinner party (see Classen et al., 1994, pp. 20-26).
} 
Heston Blumenthal, meanwhile, has been known to use the scent of the sweet shop in order, in some sense, to help extend the dining experience and hopefully trigger positive emotions in the mind of the diners (Spence \& Piqueras-Fiszman, 2014). Of course, one has to be careful not to overdo things when it comes to the use of scene-setting scents. Just take the experience of one diner writing recently on TripAdvisor about their experience at The Fat Duck recently who states that: "The final dish was 'going to bed' and I think was meant to be reminiscent of being a baby, but the smell of baby talc was overwhelming and that's not an aroma one necessarily wants while eating." (downloaded from https://www.tripadvisor.co.uk/Restaurant_Review-g528798-d1571626-Reviews-

The_Fat_Duck-Bray_on_Thames_Berkshire_England.html on 13/02/2016). While this was certainly not your author's recollection of the dish, the quote does, I think, illustrate the danger for those working in this space (i.e., trying to use both a background scent together with the foreground aroma of the food itself). ${ }^{5}$ That said, those working in the cognitive neuroscience study of multisensory perception might well have a few suggestions/tips here for the modernist chef/molecular mixologist concerning how best to convince the diner's brain to segregate the background smell of the setting from the foreground aroma of the food itself (assuming that that is the chef's aim).

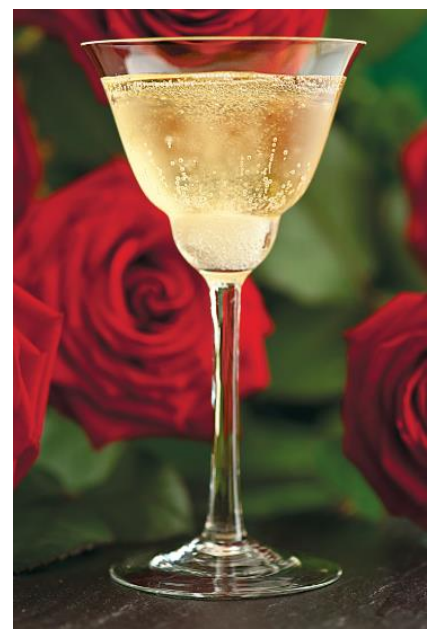

Figure 4. 'The Rose' cocktail as served by Tony Conigliaro, of 69 $\begin{array}{llll}\text { Colbrooke } & \text { Row. } & \text { [Figure } & \text { reproduced }\end{array}$ http://thehappyfoodie.co.uk/recipes/the-rose.]

\footnotetext{
${ }^{5}$ I am also reminded here of Per Se, in New York (http://www.thomaskeller.com/per-se) where the staff are banned from wearing any kind of scented product for fear that the smell of their perfume or aftershave might interfere with the diner's enjoyment of the aroma and flavour of the food (see Damrosch, 2008, p. 22; cf. Peynaud, 1987).
} 
'The rose' is the name of one of the innovative cocktails served by top mixologist, Tony Conigliaro, of 69 Colbrooke Row (http://www.69colebrookerow.com/\#about). Basically, the drink consists of a sugar cube with a few drops of rose oil which is dropped into a glass of champagne (Hyslop, 2014). The idea here was that as the drink sits in front of the customer, the smell of roses would transport them to a pleasant (not to mention fragrant) summer afternoon somewhere in their memory (see Figure 4). Here, one can think of scent and aroma as playing a role much like the projections, or musical scores or specially composed soundscapes, that one finds these days accompanying each of the dishes on the tasting menu at top experiential restaurants like Ultraviolet in Shanghai and Sublimotion in Ibiza (see Moore, 2015; Piggott, 2015; Spence \& Piqueras-Fiszman, 2014).

It can, I think, be argued that Conigliaro's innovative design is then, in some sense analogous, to Blumenthal's use of sound to transport the diner to reminisce about a pleasant childhood holiday with his Sound of the Sea seafood dish (see Blumenthal, 2008). In a way, all of these innovative food presentations can be framed as attempts to capture the essence of the Provencal Rosé paradox - this, the name given to the experience that every one of us has likely had of wines that tasted better on the shores of the Mediterranean on a summer holiday than when the same bottle is tasted back at home on a cold winter's night (Spence \& Piqueras-Fiszman, 2014). The advantage of scent here though being that it is meant to have a closer, more direct, connection with the emotional and memory circuits in the brain than any of the other senses (e.g., Chu \& Downes, 2000, 2002; Herz \& Schooler, 2002).

More futuristically, chef Andoni from Mugaritz in San Sebastian, recently voted one of the world's top 50 restaurants (http://www.theworlds50best.com/list/1-50-winners/Mugaritz), has been using the Scentee, a scent-enabled plug-in for mobile devices (http://scenteeusa.com/), to extend his interaction with diners. Specifically, the aim here is to allow those who have made a booking at his 2 Michelin-starred restaurant, to experience the actions, aromas, and sounds that accompany one of the dishes on the tasting menu by downloading the appropriate app (see Figure 5). 


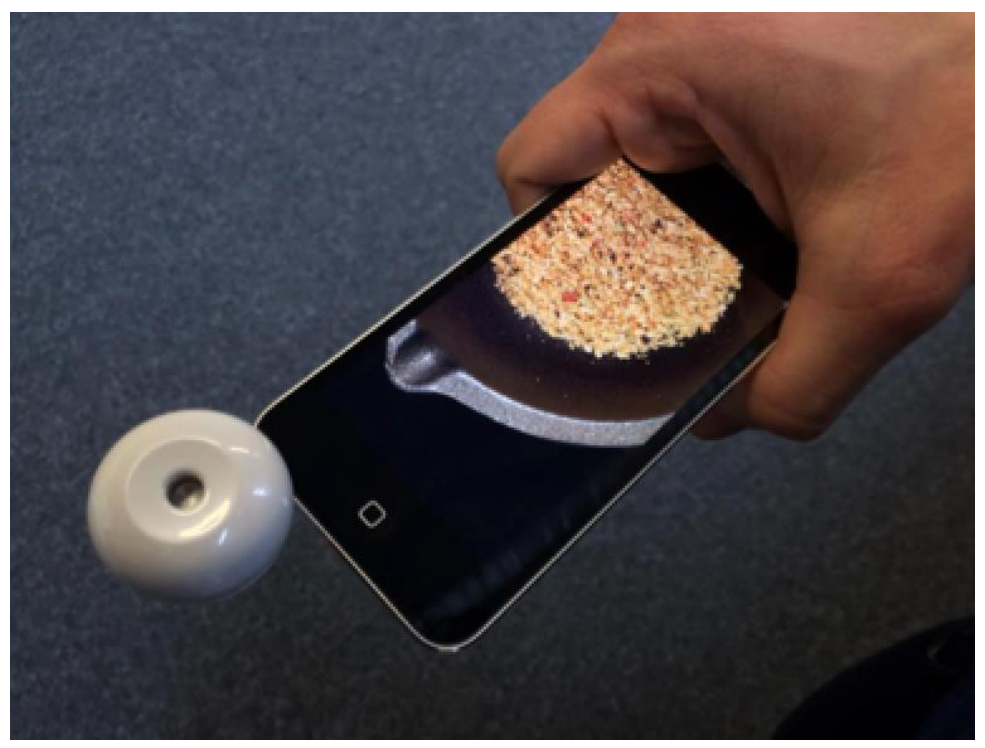

Figure 5. This scent-enabled app helps build up the anticipation and expectation in the mind of the diner through scent for those who have booked a table at Mugaritz in Spain. [Figure reproduced from Braun et al. (2016).]

If smell is indeed such an important part of what we taste, and such an effective means of triggering moods, emotions, and memories, then any one of the innovative approaches mentioned so far in this review could, I think, make sense, from the gastrophysics perspective. $^{6}$

\section{$\underline{\text { Aroma-enhanced design for the mass-market }}$}

Where the modernist chefs, molecular mixologists, and culinary designers lead though, food and beverage manufacturers are never far behind. Interesting in this regard are those companies who are starting to deliver aroma to the food and drink they provide through commercial packaging, glassware, and cutlery. PepsiCo, for instance, submitted a patent application in 2013 for the use of encapsulated aroma in the opening of their products (Morran, 2013). The Drink Right cup will be launched

\footnotetext{
${ }^{6}$ And going further afield, one might also consider the Hilton Doubletree chain's use of an aromatic sweet cookie on arrival (and which has a habit of scenting the lobby with a sweet smell) as the ultimate commercialization of food-based scent and flavour marketing (see Spence, 2002, 2015c; Spence et al., 2014).
} 
(https://www.facebook.com/TheRightCup/; e.g., O’Hare, 2015). This glass drinking vessel contains a colourful aromatic sleeve that gives off the aroma of apple, orange, or lemon (see Figure 6). The idea is that consumers pour water into the cup and have a tasting experience that approximates what might be expected on actually drinking the appropriate fruit juice, or at least fruit-flavoured water. It will, of course, be interesting to see just how important the colour cues provided by the sleeve are to the tasting experience in this case (see Spence, 2015d). Meanwhile, Molecule-R currently sells their Aromafork. The aim here is to deliver flavour with every mouthful (http://moleculargastronomy.com/; Bloom, 2014). However, I am not so convinced that their suggestion that these scented forks are ideal for the home chef who has forgotten to add a particular ingredient is really the right way to go.

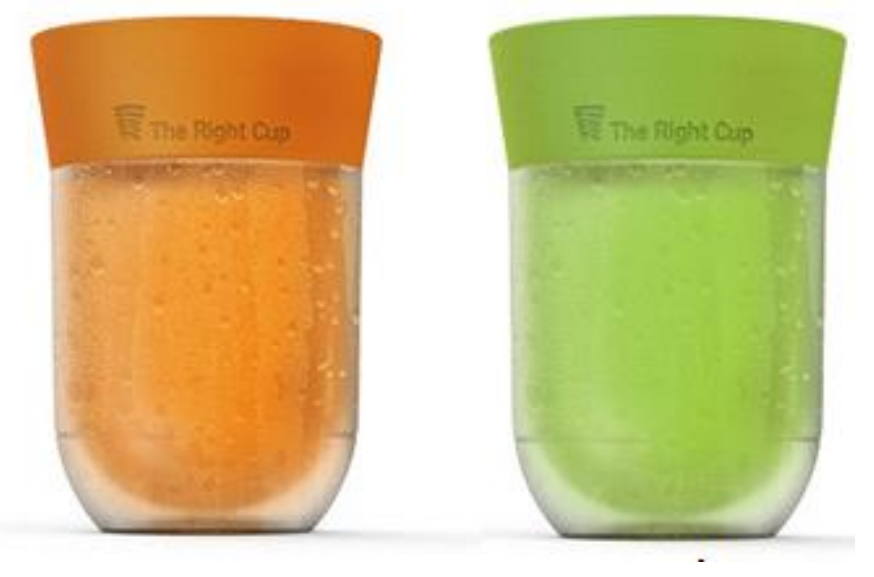

Figure 6. The Drink Right cup - Orange-flavoured on the left and apple on the right. [Figure reprinted from Bloom (2014).]

I have not yet had the opportunity to try the Right Cup, but my experience with the Aromafork leads me to believe that unless one is very careful, the tasting experience can all too easily end up as synthetic. ${ }^{7}$ This is not to say that we can always distinguish synthetic aromas from their natural counterparts, for very often, in fact, we cannot (e.g., Classen et al., 1994, pp. 197-200; Rosenbaum, 1979; Shell, 1979). It is just that the aromas sold with the Aromafork kit tend, for whatever reason, to smell cheap and artificial (presumably because that is just what they are). Just take the following quote from a blog to get the idea of someone who is using a basil-scented Aromafork to try and augment their tomato and

\footnotetext{
7 This was certainly the response of the guests on the Radio 4 show, The Kitchen Cabinet, when I tried the Aromafork on them early in 2016.
} 
mozzarella salad: "This was reminiscent of a caprese salad, but like one of those caprese salads where the basil is a little weak. You know, just kind of anemic tasting ... definitely not organic." (Lower, 2014). I would imagine that the real benefit here would come from the use of some expensive aroma in one's fork - just think of the delicious aroma of truffle, for instance.

Will such augmented approaches to food aroma delivery succeed in the marketplace in the long-term? I believe that the answer to this question will depend on the ability of those concerned to deliver quality aromas at a reasonable price, aromas that are indistinguishable from the real thing, or at least what the consumer perceives as such. For, once the consumer realizes that the aroma that they are sniffing orthonasally doesn't originate from the food or beverage that is being tasted, but instead comes from the cutlery, glassware, or packaging, they may be primed to think synthetic/artificial. ${ }^{8}$ It is that belief, as much as the evidence before their nostrils, that will likely lead to reduced hedonic ratings (this despite the undoubted novelty of these interventions). ${ }^{9}$

This, at least, would seem to be what happens when considering the literature on the effects of beliefs regarding organic food, low-fat food, branding, etc., on the response of consumers (e.g., Anderson \& Barrett, 2016; Anonymous. 2013; Lee et al., 2013; Linder et al., 2010; Sörqvist et al., 2013; Spence, 2010). While we are on this point, though, it is interesting to note how often the modernist chefs seem to stress, either explicitly or otherwise, the natural origins of their off-the-plate aromas. Be it the aroma released when hot water is poured over the all-too-real hyacinths in which one's bowl of food sits at Alinea; Or the recently deceased Homaro Cantu's use of fresh sprigs of herbs in the curly handles of his cutlery, at Moto restaurant, also in Chicago. Once again, the natural source of the off-the-plate aroma is clear for all to see.

\footnotetext{
${ }^{8}$ That said, I suppose that it is also at least conceivable that people might will one day crave such augmented, or hybrid, aromatic solutions in much the way they came to appreciate metallic taint of their tinned tomatoes (Rosenbaum, 1979). When the canning technology improved such that this 'fault' could be eliminated from tinned tomatoes, it turned out consumers had actually grown accustomed to the taste, and missed it when it was removed.

${ }^{9}$ Synthetic flavours were first introduced in the 1880's (see Rosenbaum, 1979; Wilson, 2009). Come the 1960s, one sees the complete replacement of natural flavours by synthetic, at least as illustrated by the following quote: "It's time to come back to natural flavour. Remember the real taste of luscious golden apricots or ripe juicy pineapples? Your customers do-And they are asking for real flavour. They want ingredients that are natural." - Ad by H. Kohnstamm \& Co 1972 - Food Technology, cited in Baraniuk, 2014).
} 
In fact, it would be interesting to see whether there is any relation between people's willingness to engage with such new approaches to aroma delivery and their food neophobia rating (e.g., Pliner \& Hobden, 1992; Veeck, 2010).Ultimately, we are just going to have to wait and see how the consumer of tomorrow responds to this all-new world of olfactorilyenhanced food and beverage packaging, not to mention multisensory experiential dining, drinking, and cutlery design. ${ }^{10}$ If anything, I have the feeling that the chances of success in this space will likely be enhanced by the growing trend toward 'Sensploration' that has apparently gripped many consumers recently, especially the millennials (see Aroche, 2015). All we need now is for the food and beverage companies, together with the flavour houses, to take a leaf out of the chefs' and mixologists' book, and figure out how best to stress the naturalness of their novel olfactorily-enhanced design propositions.

\section{$\underline{\text { Conclusion }}$}

While it is altogether appropriate that the space of olfactory augmentation should be explored first by those wishing to deliver unusual/enhanced multisensory tasting experiences (i.e., by the modernist chefs, molecular mixologists, culinary artists, and food designers), the hope, looking forward, has to be that enhanced olfactory design in the food and beverage sector can one day be used to help promote healthier eating behaviours as well. Could the enhanced deliver of aroma through food and beverage packaging or cutlery, say, lead not only to greater enjoyment, for instance, but also help the consumer of tomorrow to reach satiety sooner. Suggestive evidence in this regard comes from a study by Ramaekers et al. (2014) showing that enhancing the delivery of retronasal aroma while the female participants in their laboratory study ate tomato soup at lunchtime led to reach satiety sooner than another group of participants who were exposed to a reduced olfactory contribution to their food (the enhanced aroma group consumed 9\% less food). Meanwhile, Zoon de Graaf, and Boesveldt (2016) reported that females sniffing food aromas increased appetite for products that were similar in terms of their sweet/savoury taste qualities attributes and in terms of their energy density (low/high). So increase appetite for similar products food odours steer us toward intake of products with congruent macronutrient composition

\footnotetext{
${ }^{10}$ It is possible that people will one day crave such augmented, or hybrid, aromatic solutions in much the way they came to appreciate metallic taint of their tinned tomatoes (Rosenbaum, 1979). When the canning technology improved such that this 'fault' could be eliminated from tinned tomatoes, it turned out that consumers had actually grown accustomed to the taste, and missed it when it was removed.
} 
On the other hand, however, I would argue that we should all watch out for the dangers associated with our appetites being stimulated when otherwise they might not by the growing use of desirable food aromas in a whole host of public/commercial spaces (see Nassauer, 2013; Spence, 2015c).

\section{REFERENCES}

Allison, R. I., \& Uhl, K. P. (1964). Influence of beer brand identification on taste perception. Journal of Marketing Research, 1, 36-39.

Alais, D., \& Burr, D. (2004). The ventriloquist effect results from near-optimal bimodal integration. Current Biology, 14, 257-262.

Anderson, E. C., \& Barrett, L. F. (2016). Affective beliefs influence the experience of eating meat. PLOS ONE, 11(8), e0160424.

Anonymous (2011). Grant Achatz: The chef who couldn't taste. NPR, 29 ${ }^{\text {th }}$ August. Downloaded from http://www.npr.org/2011/08/29/139786504/grant-achatz-the-chef-whocouldnt-taste on $01 / 10 / 2015$.

Anonymous (2013). Does food taste better when we think it's organic? http://www.nydailynews.com/life-style/health/food-taste-better-organic-article-1.1539776.

Aroche, D. (2015). Never heard of Sensploration? Time to study up on epicure's biggest luxury trend. LuxeEpicure, December 22 ${ }^{\text {nd }}$. http://www.justluxe.com/lifestyle/dining/feature1962122.php.

Ayabe-Kanamura, S., Schicker, I., Laska, M., Hudson, R., Distel, H., Kobayakawa, T., \& Saito, S. (1998). Differences in perception of everyday odors: A Japanese-German crosscultural study. Chemical Senses, 23, 31-38.

Baraniuk, C. (2015). Fake flavours. BBC Online, August $29^{\text {th }}$. Downloaded from http://www.bbc.com/future/story/20140829-the-secrets-of-fake-flavours on 03/12/2016.

Bloom, D. (2014). Revolutionary new fork that adds own flavour to each mouthful is the latest foodie gadget to hit the market. Daily Mail Online, $\mathbf{2 3}^{\text {rd }}$ March. Downloaded from http://www.dailymail.co.uk/sciencetech/article-2587272/Revolutionary-new-fork-addsflavour-mouthful-latest-foodie-gadget-hit-market.html on 05/11/2014.

Blumenthal, H. (2008). The big Fat Duck cookbook. London, UK: Bloomsbury. 
Braun, M. H., Pradana, G. A., Cheok, A. D., Buchanan, G., Velasco, C., Spence, C., \& Aduriz, A. L., Gross, J., \& Lasa, D. (2016). Emotional priming of digital images through mobile tele-smell and virtual food. International Journal of Food Design, 1, 29-45.

Cable, S. (2014). What does Scotland smell like? Heathrow 'Scent Globe' sprays fragrance that encapsulates heather-capped Highlands and crisp loch air. Daily Mail Online, December $9^{\text {th }}$. http://www.dailymail.co.uk/travel/travel_news/article-2866889/Heathrow-Scent-Globesprays-fragrance-encapsulates-Scotland-s-heather-capped-Highlands-crisp-loch-air.html.

Chu, S., \& Downes, J. J. (2000). Odour-evoked autobiographical memories: Psychological investigations of Proustian phenomena. Chemical Senses, 25, 111-116.

Chu, S., \& Downes, J. J. (2002). Proust nose best: Odours are better cues of autobiographical memory. Memory \& Cognition, 30, 511-518.

Classen, C., Howes, D., \& Synnott, A. (1994). Aroma: The cultural history of smell. London, UK: Routledge.

Classen, C., Howes, D., \& Synnott, A. (2005). Artificial flavours. In C. Korsmeyer (Ed.), The taste culture reader: Experiencing food and drink (pp. 337-342). Oxford, UK: Berg.

Damrosch, P. (2008). Service included: Four-star secrets of an eavesdropping waiter. New York, NY: William Morrow.

Elzinga, K. G. Tremblay, C. H. \& Tremblay, V. J. (2015). Craft beer in the United States: History, numbers, and geography. Journal of Wine Economics, 10, 242-274.

Fincks, H. T. (1886). The gastronomic value of odours. Contemporary Review, 50, 680-695.

Herz, R. S., \& Schooler, J. W. (2002). A naturalistic study of autobiographical memories evoked by olfactory and visual cues: Testing the Proustian hypothesis. American Journal of Psychology, 115, 21-32.

Hollingworth, H. L., \& Poffenberger, A. T. (1917). The sense of taste. New York, NY: Moffat Yard.

Hyslop, L. (2014). Anyone for horseradish vodka? Meet cocktail wizard Tony Conigliaro. The Daily Telegraph, $\mathbf{1 6}^{\text {th }}$ September. Downloaded from http://www.telegraph.co.uk/foodanddrink/11099017/Anyone-for-horseradish-vodka-Meetcocktail-wizard-Tony-Conigliaro.html on 14/02/2015.

Koutsovoulou, E. (2014). Chandler Burr: "Take your seat to a scent dinner". Fine Dining Lovers, June 26. Downloaded from https://www.finedininglovers.com/stories/chandler-burrinterview-scent-dinner/ on 20/07/2015.

Lapis, T. J., Penner, M. H., \& Lim, J. (2016). Humans can taste glucose oligomers independent of the hT1R2/hT1R3 sweet taste receptor. Chemical Senses. 
Lee, W. J., Shimizu, M., Kniffin, K. M., \& Wansink, B. (2013). You taste what you see: Do organic labels bias taste perceptions? Food Quality and Preference, 29, 33-39.

Lim, J., \& Johnson, M. B. (2011). Potential mechanisms of retronasal odor referral to the mouth. Chemical Senses, 36, 283-289.

Lim, J., \& Johnson, M. (2012). The role of congruency in retronasal odor referral to the mouth. Chemical Senses, 37, 515-521.

Linder, N. S., Uhl, G., Fliessbach, K., Trautner, P., Elger, C. E., et al. (2010). Organic labeling influences food valuation and choice. NeuroImage, 53, 215-220.

Lower, C. (2014). I used an aromatherapy fork to confuse and disturb my body. My broccoli didn't magically taste like strawberry candy, but it did taste less like broccoli. October $9^{\text {th }}$. Downloaded from http://www.xojane.com/fun/molecule-r-aromafork on 15/02/2016.

Mangen, G. (2014). Flipping your lid: New coffee cup aims at your nose. $C N B C$, April 26 ${ }^{\text {th }}$. Downloaded from http://www.cnbc.com/2014/04/25/coffee-lid-gets-aredesign-to-let-thearoma-in.html on 30/08/2015.

Marinetti, F. T., \& Colombo, L. (1930/1998). La cucina futurista: Un pranzo che evitò un suicidio [The Futurist kitchen: A meal that prevented suicide]. Milan: Christian Marinotti Edizioni.

Moore, M. (2015). Taste the difference. The Financial Times Weekend, August 30 ${ }^{\text {th }}$ (Life $\&$ Arts), 1-2.

Morran, C. (2013). PepsiCo thinks its drinks aren't smelly enough, wants to add scent capsules. Consumerist, September $17^{\text {th }}$. Downloaded from http://consumerist.com/2013/09/17/pepsico-thinks-its-drinks-arent-smelly-enough-wants-toadd-scent-capsules/ on 24/07/2015.

Nassauer, S. (2014). Using scent as a marketing tool, stores hope it--and shoppers--will linger: How Cinnabon, Lush Cosmetics, Panera Bread regulate smells in stores to get you to spend more. The Wall Street Journal, May 20 ${ }^{\text {th }}$. Downloaded from http://www.wsj.com/articles/SB10001424052702303468704579573953132979382 24/07/2015.

Ni, R., Michalski, M. H., Brown, E., Doan, N., Zinter, J., Ouellette, N. T., \& Shepherd, G. M. (2015). Optimal directional volatile transport in retronasal olfaction. Proceedings of the National Academy of Sciences of the USA, 112, 14700-14704.

O'Hare, R. (2015). The mind-bending beaker that tricks your brain into thinking water tastes like juice: $£ 25$ Right Cup uses fruity aromas to confuse the senses. DailyMail Online, December 30 $^{\text {th }}$. Downloaded from http://www.dailymail.co.uk/sciencetech/article3378689/Mind-bending-beaker-tricks-brain-thinking-water-tastes-like-juice-25-Right-Cupuses-fruity-aromas-confuse-senses.html on 08/02/2016. 
Peynaud, E. (1987). The taste of wine: The art and science of wine appreciation (Trans. M. Schuster). London, UK: Macdonald \& Co.

Pigott, S. (2015). Appetite for invention. Robb Report, May, 98-101.

Piqueras-Fiszman, B., \& Spence, C. (2015). Sensory expectations based on product-extrinsic food cues: An interdisciplinary review of the empirical evidence and theoretical accounts. Food Quality \& Preference, 40, 165-179.

Pliner, P., \& Hobden, K. (1992). Development of a scale to measure the trait of food neophobia in humans. Appetite, 19, 105-120.

Ramaekers, M. G., Luning, P. A., Ruijschop, R. M., Lakemond, C. M., Bult, J. H., Gort, G., \& van Boekel, M. A. (2014). Aroma exposure time and aroma concentration in relation to satiation. British Journal of Nutrition, 111, 554-562.

Robinson, J. (2014). Lager? It all tastes the same: Drinkers struggle to distinguish between big name brands in blind taste tests. Daily Mail Online, August $\mathbf{1 3}^{\text {th }}$. http://www.dailymail.co.uk/news/article-2723583/Lager-It-tastes-Drinkers-struggledistinguish-big-brands-blind-taste-tests.html.

Rosenbaum, R. (1979). Today the strawberry, tomorrow... In N. Klein (Ed.), Culture, curers and contagion (pp. 80-93). Novato, CA: Chandler and Sharp.

Rozin, P. (1982). "Taste-smell confusions" and the duality of the olfactory sense. Perception \& Psychophysics, 31, 397-401.

Shell, E. R. (1979). Chemists whip up a tasty mess of artificial flavors. Smithsonion, 17(1), 79 .

Sörqvist, P., Hedblom, D., Holmgren, M., Haga, A., Langeborg, L., Nöstl, A., et al. (2013). Who needs cream and sugar when there is eco-labeling? Taste and willingness to pay for "eco-friendly" coffee. PLoS One, 8(12):1-9.

Spence, C. (2002). The ICI report on the secret of the senses. London, UK: The Communication Group.

Spence, C. (2010). The price of everything - the value of nothing? The World of Fine Wine, 30, 114-120.

Spence, C. (2015a). Just how much of what we taste derives from the sense of smell? Flavour, 4:30.

Spence, C. (2015b). Multisensory flavour perception. Cell, 161, 24-35.

Spence, C. (2015c). Leading the consumer by the nose: On the commercialization of olfactory-design for the food \& beverage sector. Flavour, 4:31.

Spence, C. (2015d). On the psychological impact of food colour. Flavour, 4:21. 
Spence, C. (2016). Oral referral: Mislocalizing odours to the mouth. Food Quality \& Preference, 50, 117-128.

Spence, C., \& Piqueras-Fiszman, B. (2014). The perfect meal: The multisensory science of food and dining. Oxford, UK: Wiley-Blackwell.

Spence, C., Puccinelli, N. Grewal, D., \& Roggeveen, A. L. (2014). Store atmospherics: A multisensory perspective. Psychology \& Marketing, 31, 472-488.

Spence, C., \& Wan, I. (2015). Beverage perception \& consumption: The influence of the container on the perception of the contents. Food Quality \& Preference, 39, 131-140.

Spence, C., \& Youssef, J. (2015). Olfactory dining: Designing for the dominant sense. Flavour, 4:32.

Stuckey, B. (2012). Taste what you're missing: The passionate eater's guide to why good food tastes good. London, UK: Free Press.

Veeck, A. (2010). Encounters with extreme foods: Neophilic/neophobic tendencies and novel foods. Journal of Food Products Marketing, 16, 246-260.

Wilson, B. (2009). Swindled: From poison sweets to counterfeit coffee - The dark history of the food cheats. London, UK: John Murray.

Yeap, N. (2015). Airport superchef: Heston Blumenthal. CNN Money, August $7^{\text {th }}$. Downloaded from http://money.cnn.com/2015/08/07/luxury/heston-blumenthal-airport-chefrestaurant-london/ on 15/02/2016.

Zoon, H. F. A., de Graaf, C., \& Boesveldt, S. (2016). Food odours direct specific appetite. Foods, 5:12. 